\title{
Training of modern specialists based on V.I. Vernadsky's ideas of noosphere education
}

\author{
Natalia Gorbunova ${ }^{1}$, Irina Osadchaia $^{1}$, and Olga Ignatova $^{1}$ \\ ${ }^{1}$ V. I. Vernadsky Crimean Federal University, 298600, Simferopol, Russia
}

\begin{abstract}
The article is devoted to the study of topical problems of noosphere education and noosphere pedagogy on the analysis of the development of the modern higher education system in the Russian Federation. An analysis of the reflection of the main noosphere ideas in modern education is presented. Theoretical provisions on creativity as a feature of noospheric pedagogy (corresponding to the spirit of time and the challenges of the modern globalized world) are revealed. The article reveals the importance of future educators forming humanistic-oriented personality qualities based on the implementation of new approaches to education, consistent with the natural laws of the universe, not violating the biorhythms of living systems, but taking into account the capabilities of the psyche, human nature, its age characteristics, individual pace of development. The main task of pedagogical education from the point of view of the noosphere concept is determined - the formation in a person of a holistic noosphere consciousness (holistic thinking, an ethical bioadaptable method of behavior and an ecological worldview).
\end{abstract}

\section{Introduction}

In the current conditions of intensive development of society:

- on the one hand, there is digitalization, computerization, robotization of all spheres of human life (smart home; smart robots - service in hotels and restaurants; the Internet is used by majority as the main source of information),

- on the other hand, in the context of the pandemic, there was an urgent need to move educational institutions of different levels to the implementation of the educational process in the format of using distance learning technologies [1].

Everything mentioned above actualizes the need to organize such type of education, the basic provisions of which should reflect installation for the formation of abilities for adequate human behavior in conditions of contradictions between humanity and nature, man and society. Both new resources (human, intellectual, technical, material) and new tools (forms, methods, technologies, support) should be found and implemented to eliminate the contradictions, to create pedagogical conditions of the harmonious, corevolutionary existence of all living and non-living on the planet. These changes also imply mandatory changes in the field of interaction of all subjects of the educational process.

${ }^{1}$ Corresponding author: natalya-gor2008@yandex.ru 
In this regard, the relevance of the "noosphere," "noosphere thinking," "noosphere education" increases, as the modern education system should also be updated and built on the basis of natural structural and functional rules of the World order, that is, the General Laws of the World. However, it means that everyone should aware of oneself not only as a citizen of his country, but also a citizen of the World, professing high moral qualities and humanistic ideals, values and norms. In case to understand the causes of existing problems and find them optimal decision humanity must not ignore the civilian responsibility for the fate of the planet and all mankind.

This scientific paper is devoted to analysis of the pedagogical concept of noosphere pedagogy in the context of using its provisions to construct the efficient educational process in the University.

The advantages of noosphere approach in education were analysed in the researches of such prominent scientists as: O.V. Dabanova, T.I. Emelyanova, M.S. Goncharenko, M.G. Kulikova, M.N. Kurik, N.V. Maslova, E.E. Shishlova.

\section{Materials and the results of the research}

Solving new problems and achieving new results in education corresponds to the concept of the noosphere that is a multifaceted philosophical system in which both the transcendental properties of the human mind and the entire palette of human activity growing out of the ability to think fit [2].

The concept of the noosphere as the highest social value puts the development of a free person in a harmonious environment. Thus, the concept of the noosphere meets the ideals of humanism. Elements of the noosphere are creative discoveries, spiritual values, scientific ideas, artistic works, technical complexes. The use of nootechnologies can ensure the sustainable development of the noosphere, including the sustainable development of noocommunity. The consciousness of man and humanity gives the noosphere a constructive character, the possibility of targeting, design and prediction arises $[3,4,5]$.

Noospheric pedagogy develops specific principles and methods for managing the educational process, in the unity of such sciences as ecology, psychology, synergy, neurophysiology, pedagogy [6].

Noosphere education (as a holistic pedagogical system) is an advanced education creating the conditions for the development of a Person with a coevolutionary worldview, percepting and realizing himself as part of Space, responsible for life in any of its manifestations [7].

Noospheric formation is a new stage in the evolution of education. The objective of noosphere education is to develop creative, healthy thinking students, adequate to the nature of the brain. The noospheric personality, of course, should inherent self-sufficiency, internal harmony and a noospheric consciousness, which is different from the human consciousness of man-made civilization. Technologically, using five channels of human perception (vision, hearing, touch, smell, taste), intensification of creative thinking and a holistic scientific view of the phenomena studied is proposed to solve such a problem. Turning to the student's personal experience and the natural biorhythms of the body gives a reduction in the study time of the subject by 3-6 times, releases health resources, leads to savings in material and financial costs and makes it possible to increase the efficiency of assimilation of knowledge and acquisition of skills as much as possible [8, 9].

Noospheric education, as a methodology, is characterized from different points of view: - Environmentally friendly, improving the health of a student and a teacher,

- bioadaptable: it is based on natural processes of receiving and transmitting information, develops harmonious, holistic thinking and develops bioadaptive thinking; 
- biosphere, - does not aim to subordinate nature to man (anthropocentrism), focusing on the co-development of nature, man, space;

- scientific, - it is based on the modern achievements of the natural sciences, humanities;

- systemic, - considers the subsystem "man-society" in the systems "nature" and "space" and is based on the idea of genetic energy information unity of the World;

- creative, - implements the creative capabilities of teachers and students;

- biorhythmic (relaxation-active) in the form of organization of classes (alternation of educational and creative recreation and activity);

- harmonious, - ensures the joy of knowledge, self-realization at all levels of human development (physical, creative, interpersonal, social, fundamental, universal);

- humane in purpose, methods and means;

- instrumental, - gives a person an instrument of thinking and further cognition without dependence on the teacher;

- cost-effective - reduces time, social, logistical and other costs by 3-6 times;

- leading, - prepares individuals with leading holistic thinking;

- innovative in basic and auxiliary components;

- progressive, - corresponds to person's natural evolution and self-realization, his bioadaptive, environmentally safe creativity;

- optimal - minimizes errors in the process of cognition/comprehension [10].

To implement the key ideas of noosphere education in the format of creative pedagogy of the 21st century, an educational collaboration, creative interaction between faculty and student youth, involving a modular organization of the educational process, was created at the Humanities and Education Science Academy of V. I. Vernadsky Crimean Federal University. The key idea is to prepare thinking young people with creative ideas based on different types of activity and leadership. The key approach in the organization of the educational process is the environmental approach aimed at forming a creative educational environment [11].

Implementation Principles:

1. Polyfunctionality of specialist training (mastering a set of additional competencies, related professions)

2. Activity and Leadership

3. Creativity

4. Interactions

Implementation Technologies:

1. Jump (promotion courses)

2. Blockchain

3. Soft-education

4. Coaching

5. Creative pedagogy

6. Digital pedagogy

7. Pedagogical design

8. Green Field (Greenfields)

9. Real technique.

The noospheric lesson is structured and its content is selected on the basis of a bioadditional technique (Real-technique), when the presentation of information is carried out according to the natural psychophysiological code of perception of educational information. Stages of bioadaptive lesson include intensification of reference knowledge, assimilation of new knowledge, formation of skills and application of knowledge. Realtechnique is a biologically adequate relaxation and active technique. It is a set of coordinated actions of a teacher and a student, the purpose of which is to form holistic dynamic thought forms in educational discipline and skills of instrumental work with them. 
In this case, a systematic organization of physiological, intellectual, mental functions of students is used. There is nothing new in teaching methods except activating creative abilities and saving thinking: this is the shortest path to the goal $[12,13,14,15,16]$.

Implementation format:

1. Co-working zone. Boiling points

2. Thematic weekends

3. Project sessions.

4. Strategic sessions.

The organization of the training of future specialists involves the development of a professional module within the framework of the principal professional educational program (OPOP) and the study of the disciplines of the curriculum; implementation in principal professional educational program (OPOP) of each direction of preparation of educational component and mastering of educational disciplines through modules:

- culture module;

- intelligent module;

- creative module;

- philological and oratory module;

- economic (marketing, logistics) module;

- legal module;

- IT module;

- leadership model $[17,18,19]$.

Projects for implementation:

1. Project "Professional of the Future."

Creative group of freshmen from each training area. Each month, students pass one of the thematic modules in the format of a creative session or thematic weekend, as a result of the development of each module, we get the result in the form of an activity product (picture, project, presentation of a musical work, etc.).

2. Creative Teacher Project

Creative Group of Teachers - Coaches by Modules. + Creative Group for Project Activities. Project sessions.

3. Creative Applicant Project. Profile classes. Psychological and pedagogical classes. Professions of the future. Innovative educational platforms.

4. Project "Summer Schools."

5. Project "Implementation of OPOP in modular format"

6. Project "Yalta - education, recreation, health, culture, tourism."

7. Project "Individual and creative training" (musicians, artists).

8. Project "Training of specialists in network format" (interaction with palaces-museums + "Historical Club" (+ interaction with other universities) + Patriot Park.

9. Project "Educational zones of intelligence". The development of intelligence. Emotional intelligence. Divergent thinking. Convergent thinking. Artificial intelligence. Teacher's Role.

10. Project "Gifted Students".

Implementing these projects and innovative teaching methods will definitely create an enabling educational environment and reform the educational process not only at the level of one university but the whole country.

\section{Conclusion}

Thus, having considered all above mentioned we can conclude that improvement of the education system and training can be managed under condition of mastering the General Laws of Planet Earth, society, management and enrichment of Education and Society, 
special laws of education and psyche and human health. The concept of noosphere formation includes a system of scientific and theoretical, methodological, medical and psychological and practical views on nature of education and ways to achieve appropriate education for younger generations. The goal of noosphere education is to focus on a healthy lifestyle and grow up a noosphere person with such characteristics as perspective thinking of what happens and can happen on the planet and in humanity, awareness of the dynamics of the world, its diversity and interdependence. By means of noosphere education educators can avoid authoritarianism, practically and economically organize a pedagogical space to change the necessary conditions and optimal technologies, create an environmental, humane educational process within the programmes of the cross-cutting development of all links of the educational process (family - kindergarten - school - university - extra training of the population). So, being implemented in V. I. Vernadsky Crimean Federal University, educational collaboration based on main principles of noosphere education, will allow to orient a person in modern society, to preserve and improve the physical, moral, mental and spiritual health of a student and a teacher, to organize the educational process in such a way as to shorten time and to give a boost to a person's natural transforming of thinking, methodology and outlook.

\section{References}

1. V. N. Vasilenko, Noosphere consciousness in the poetics of generations, To the 145th anniversary of V.I. Vernadsky, Preface to the monograph, 140 (Free sketches, Monograph, IPPC Moscow State University named after M.V. Lomonosov, Moscow: MAKS Press, 2008)

2. N.V. Kuzmina, Problems of professional training of specialists in universities, 304 (St. Petersburg: Peter, 2005)

3. M.N. Kurik, Noosphere of education in the formation of a new person, Modern education, http://osvita.ua/school/method/367/

4. N.V. Mormuzheva, Motivation for training students of professional institutions, Pedagogy: traditions and innovations, 160-163 (Chelyabinsk, 2015)

5. A.B. Myrzabayev, M.N. Shayakhmetova, B.K. Shaushekova, A.S.Yerkin, B.A. Zhekibayeva, Genesis of the concept noosphere pedagogy and the paradigm, Astra Salvensis. 6 (1), 547-563 (2018)

6. E.E. Shishlova, Sociocultural competence as a quality indicator in the professional training of specialists, Vysshee Obrazovanie v Rossii, 29 (5), 95-102 (2020)

7. D.P. Danilaev, N.N. Malivanov, Technological education and engineering pedagogy, Obrazovanie i Nauka, 22 (3), 55-82 (2020)

8. N.A. Astashova, S.L. Melnikov, A.P. Tonkikh, V.L. Kamynin, Technological resources in modern higher education, Obrazovanie i Nauka, 22(6), 74-101 (2020)

9. E.F. Zeer, V.S. Tretyakova, M.V. Zinnatova, Innovative model of socio-professional development of a student's personality, Obrazovanie i Nauka, 22(3), 83-115 (2020)

10. C.M. Sigona, A.Fernández-Alonso, Cross-cultural experiences in transnational education: Preservice teachers and global perspectives, Advances in Intelligent Systems and Computing, 11th International Conference on EUropean Transnational Education, ICEUTE 2020; 196-201 (Burgos, Spain, 2020) 
11. I.G. Ndukwe, B.K. Daniel, Teaching analytics, value and tools for teacher data literacy: a systematic and tripartite approach, Int. J. of Educational Technology in Higher Education, 17 (1), 22

12. K.S. Hui, T. Khemanuwong, S.A.M.M Ismail, Keeping Teachers Afloat with Instructional Coaching: Coaching Structure and Implementation, Qualitative Report, 25 (7), 1790-1816 (2020)

13. G.P. Sikorskaya, O.B. Akimova, E.M Dorozhkin, I.V. Yakhneeva, Noospheric pedagogy: The expansion of the humanitarian space of vocational and pedagogical education, Int. J. of Environmental and Science Education, 11 (14), 6963$6975(2016)$

14. S.M Mineeva, Noosphere education in the education system of the technical school, Scientific and methodological J. Search, 1 (53), 59-62 (2016)

15. O.V. Goncharova, Noosphere education is a new peradigma in the history of environmental education in Russia, Modern science: topical problems of theory and practice, Humanities, 11, 65-68 (2016)

16. T.A. Dmitrienko, Problematic and noospheric approaches in organizing forms of modern education, Problematic and noospheric approaches in organizing forms of modern education for the sustainable development of civilization. Materials of the XVII Moscow International Conference "Education in the XXI Century - through the Eyes of Children and Adults", 46-48 (Moscow, 2017)

17. S.V. Kovalenko, Noosphere technologies of inclusive education, Bulletin of Ivanovo State University, humanities, 2 (18), 52-58 (2018)

18. T.I. Emelyanova, Laboratory of Noosphere Education, Ecology. Science, education, practice, Materials of the I All-Russian Environmental Forum named after Professor B.S. Kubantsev, 99-91 (2018)

19. O.V. Dabanova, Formation of a noospheric worldview of a student through the inclusion of a system of noospheric ideas in the content of education, New science: experience, traditions, innovations, 8-1, 33-36 (2016) 